\title{
Leisure Involvement and Happiness Levels of Individuals Having Fitness Center Membership
}

\author{
Mehmet Demirel $^{1}$ \\ ${ }^{1}$ Necmettin Erbakan University, Tourism Faculty, Department of Recreation Management, Turkey \\ Corresponding: Mehmet Demirel, Necmettin Erbakan University, Tourism Faculty, Department of Recreation \\ Management, Turkey. E-mail: mehmetdemire178@gmail.com
}

$\begin{array}{ll}\text { Received: October 2, } 2019 & \text { Accepted: October 28, } 2019 \quad \text { Online Published: November 1, } 2019 \\ \text { doi:10.5539/jel.v8n6p140 } & \text { URL: https://doi.org/10.5539/jel.v8n6p140 }\end{array}$

\begin{abstract}
The aim of the study is to investigate the leisure involvement and happiness levels of the individuals who have any fitness center membership. Screening model was used in the research. The sample group of the research was composed of a total of 599 voluntary participants, 260 being "females" and 339 being "males", who were using fitness centers and were selected using improbable purposeful sampling method. "Oxford Happiness Scale Short Form-OHS-F", developed by Hills and Argyle (2002) and adapted into Turkish by Doğan and Cotok (2011) along with "Leisure Involvement Scale-LIS-F", developed by Kyle et al. (2007) and adapted into Turkish by Gurbuz et al. (2018) were used in the study in addition to "Personal Information Form". Descriptive statistical method (frequency, arithmetic mean, standard deviation) was used for the identification of the distribution of the participants' information. In order to determine if the data had normal distribution or not, Shapiro-Wilk test for normality was conducted and in consequence of this test, t-test, single factorial MANOVA, ANOVA and Pearson Correlation tests were administered upon determining that the data were in accordance with parametric test conditions. According to the findings, while there was no significant difference found in the happiness levels in line with the gender, marital status and education levels of the participants; a significant difference was determined in the leisure involvement levels according to education level and gender, and yet no significant difference was found between the leisure involvement level and marital status. Besides, a positively significant relationship was determined between the level of happiness and leisure involvement. The restraints as well as the evaluations for future studies were discussed in this sense.
\end{abstract}

Keywords: leisure involvement, happiness, fitness

\section{Introduction}

The concept of time is becoming more and more important in today's world. A race against time, in many cases almost every period of our lives, began to pose serious problems of lack of time (Cuhadar et al., 2019). Nowadays, with the increasing importance of time management, there have been several developments in how the individuals make use of leisure times out of the business world, the leisure involvement criteria as well as the concept of happiness level of the individuals; and the activities within this scope and evaluation methods have gained importance.

In the present century we live in, the rapid increase in the scientific and technological developments, industrial developments as well as the immense progresses in communal development and prosperity have given rise to a reaction to working which paved the way for the increasing interest in leisure times. As a result of the conveniences provided in the life conditions and the decrease in the working hours of the individuals, we can see that there has been an increase in leisure times (Demirel \& Harmandar, 2009; Tolukan, 2010; Serdar \& Ay, 2016). The increase in leisure times and people's adaptation to the shifts occurring in other areas of life have made substantial contributions in facilitating and extending people's lives and also enjoying the life to a greater extent by sparing time for themselves (Kocak, 2017; Gurbuz et al., 2018). While developing instructional programs, personality-improving activities with branch specific knowledge can be incorporated into curricula (Turan \& Koc, 2018). In broader terms, recreation and the concepts of recreation have become one of the ways to maintain the mental and physical health of humans in this changing and developing world (Demirel et al., 2017).

As summarized by Roberts (2006) and Tezcan (1994); leisure time was defined as the amount of time spent away from work, sleep and liabilities, and the activities done in the residual time frame were called leisure time activities 
(Ardahan \& Yerlisu Lapa, 2010). Leisure time activities are the activities that individuals are motivated from in order to obtain the goods and services in line with their objectives to participate in the activity, and accordingly carry out with various actions and thoughts (Stebbins, 2016; Eskiler \& Karakas, 2017). With another viewpoint, Broadhurst defined recreation as activities encompassing versatile, physical, affective, social and cognitive components that individuals participate in their leisure times (Broadhurst, 2001; Yalcin et al., 2017). Although people have different purposes behind their participation in leisure time activities, they all have one common point. The individual participates in a leisure activity in order to take delight in it and feel satisfied as a result of this delight (Celik, 2011)

With the increasing interest of the individuals in leisure times, the individuals have been in a search of making use of their spare times. As the preferences for making use of these spare times vary in line with the requests, needs and expectations of the individuals, the issue of involvement gains importance at this point (Yetim \& Argan, 2018). Leisure involvement is defined as "the unperceivable situation of the interest and attention shown in a recreational activity or its by-product that orientates one's characteristics and is triggered by certain conditions and impulses". Although, in this sense, leisure involvement is generally perceived as multi-dimensional structures, in many studies it was stated that leisure involvement was a structure that was positively associated with the involvement period, involvement intensity, involvement frequency and efficiency (Havitz et al., 2013; Aydın, 2016). Recreational activities in leisure time play an important role in coping with physiological and psychological problems that are an inevitable result of daily life and keeping the individual healthy (Cuhadar et al., 2019).

Measuring whether or not the individuals gain the desired benefits from the leisure time activities, these activities meet their expectations and participating in such activities would make them feel satisfied can provide great insights into the precautions to be taken that would help them feel much happier and satisfied while making use of their spare times as well as into the development of the leisure time activities provided in accordance with their satisfaction levels (Karlı et al., 2008; Ardahan \& Yerlisu Lapa, 2010). Artistic and cultural activities that enhance socialization can be incorporated more into the instructional programs (Koc \& Turan, 2018)

Happiness, although seemingly and conceptually easy to define due to its frequent use in daily life, is actually a broad concept that is very comprehensive to explain. Although many other concepts such as joy, peace, thrill and satisfaction seem to reflect happiness, these words are actually not enough to define happiness (Marar, 2004; Aydın, 2016). The reason behind this is the fact that there are various conditions underlying the happiness of individuals and that the meaning of "happiness" has either a broad or narrow sense (Tuzgol, 2004; Sevin \& Sen, 2019). Happiness or in other words, subjective well-being has for long grabbed the attention of the researchers as a concept that has a substantial impact on many aspects and fields of human life. Subjective well-being is the predominance of an individual's positive emotions over the negative ones and is generally defined as the satisfaction out of life (Ozdemir \& Koruklu, 2011; Goral, 2013). Maintaining a happy life is undoubtedly one of the leading life goals for many people. It is known that happiness, which is tried to be "understood" and "obtained" by means of questions such as how one can be happy, what happiness means and what factors have an influence on it, has been an important issue for people (Çivitçi, 2012; Soyer et al., 2017).

Among the predictive factors of happiness can be found the satisfaction out of the leisure time, the frequency of physical activity, the education and income level of the individual, marriage, life satisfaction, optimism and physical health status. In addition, factors such as the means of social interaction, number of friends and the frequency of social activities have substantial effects on the level of happiness (Bailey \& Fernando, 2012; Karacar, 2019; Koc \& Pepe, 2018).

When the studies related to leisure involvement and happiness within the body of literature are examines, Reich and Zautra (1981) stated that a continuing involvement in leisure activities reduced the daily stress and increased psychological happiness (Cenkseven \& Sar1, 2009). Providing an emotion of satisfaction, embodying a certain lifestyle, comprising beliefs and representing the way of expression of ideal life; leisure time is used in the fulfillment of the sense of happiness such as achieving a healthy body and a high-quality life (Lin et al., 2014; Aydin, 2016).

The physical activities that individuals carry out in their leisure times have substantial benefits on their life quality. These activities help individuals with their lives by guiding them with respect to satisfying their demands and requests and needs about life. In many studies in which the relationship between happiness and leisure involvement was investigated, it was determined that people's participation in leisure time activities made positive contributions to their state of well-being and happiness (Brajssa et al., 2011; Dogan, 2018).

This study, hereby, aimed to make a contribution to recreation literature by analyzing the relationship between happiness and the reasons behind the individuals' participation in leisure time activities (fitness) and level of 
involvement.

\section{Methodology}

\subsection{Research Model}

The screening model was used in the research. In the screening model; in which the past or present situation is depicted in its present form, the important thing is to be able to define the individual or object, discussed in this research, as is in the present conditions and observe the present situation without changing it (Karasar, 2012).

\section{Research Group}

The sample group of the research is composed of a total of 599 voluntary participants, 260 being "females" and 339 being "males", who were selected using the improbable purposeful sampling method and were using the fitness centers in the city of Kayseri.

\section{Data Collection Tools}

In the research, "Personal Information Form", "Oxford Happiness Scale - Short Form" and "Leisure Involvement Scale" was used as data collection tools.

\subsection{Personal Information Form}

The "Personal Information Form" developed by the researchers was used to gather data in relation to the gender, age, marital status, monthly income, educational status, daily leisure time spent and weekly usage frequency of the participants.

\section{Oxford Happiness Scale - Short Form}

"Oxford Happiness Scale Short Form OHS-F", developed by Hills and Argyle (2002) and adapted into Turkish by Dogan and Cotok (2011) was used. Oxford Happiness Scale consists of 7 expressions in one sub-dimension. The expressions on the 5-item Likert scale are answered as (1) Disagree - (5) Completely agree.

\subsection{Leisure Involvement Scale}

In order to measure the leisure involvement levels of the participants; "Leisure Involvement Scale-LIS", developed by Kyle et al. (2007) and adapted into Turkish by Gurbuz et al. (2018), was used. Leisure Involvement Scale is composed of a total of 15 items, equally distributed ( 3 items each) 5 sub-dimensions. The sub-dimensions of the scale are (1) Attractiveness (2) Giving importance (3) Social Interaction (4) Identification (5) Self-expression. The expressions on 5-item Likert scale can be answered as: (1) Completely Disagree - (5) Completely Agree.

\subsection{Data Analysis}

Descriptive statistics method was used for the identification of the distribution of the participants' personal information (frequency, arithmetic mean, standard deviation). In order to determine if the data had normal distribution or not, Shapiro-Wilk test for normality was conducted and in consequence of this test, t-test, single factorial MANOVA, ANOVA and Pearson Correlation tests were administered upon determining that the data were in accordance with parametric test conditions. 


\section{Findings}

Table 1. Personal information distribution of the participants

\begin{tabular}{|c|c|c|c|}
\hline Variables & & $\mathrm{F}$ & $\%$ \\
\hline \multirow[t]{3}{*}{ Gender } & Male & 339 & $\overline{56.6}$ \\
\hline & Female & 260 & 43.4 \\
\hline & Total & 599 & 100 \\
\hline \multirow[t]{5}{*}{ Age } & Age 20 and below & 105 & 17.5 \\
\hline & Age 21-30 & 342 & 57.1 \\
\hline & Age $31-40$ & 49 & 8.2 \\
\hline & Age 41 and above & 103 & 17.2 \\
\hline & Total & 599 & 100 \\
\hline \multirow[t]{3}{*}{ Marital Status } & Married & 171 & 28.5 \\
\hline & Single & 428 & 71.5 \\
\hline & Total & 599 & 100 \\
\hline \multirow[t]{4}{*}{ Educational Status } & High School & 137 & 22.9 \\
\hline & Associate Degree & 113 & 18.9 \\
\hline & Bachelor's Degree & 349 & 58.3 \\
\hline & Total & 599 & 100 \\
\hline \multirow[t]{7}{*}{ Monthly Income Status } & $1000 \mathrm{TL}$ and below & 220 & 36.7 \\
\hline & $1001-1500$ & 100 & 16.7 \\
\hline & $1501-2000$ & 63 & 10.5 \\
\hline & $2001-2500$ & 78 & 13.0 \\
\hline & $2501-3000$ & 88 & 14.7 \\
\hline & $3001 \mathrm{TL}$ and above & 50 & 8.3 \\
\hline & Total & 599 & 100 \\
\hline \multirow[t]{4}{*}{ Weekly Usage Frequency } & 1-2 Days & 203 & 33.9 \\
\hline & 3-4 Days & 229 & 38.2 \\
\hline & 5 Days & 167 & 27.9 \\
\hline & Total & 599 & 100 \\
\hline \multirow[t]{4}{*}{ Time Spent Weekly } & 1 Hour and below & 169 & 28.2 \\
\hline & 2 Hours & 276 & 46.1 \\
\hline & 3 Hours & 154 & 25.7 \\
\hline & Total & 599 & 100 \\
\hline
\end{tabular}

Table 1 presents the statistical findings related to the participants' gender, age, marital status, educational status, monthly income level, weekly usage frequency and the time periods spent weekly. According to the analysis results, it was determined that, of the participants; $56.6 \%$ was "Male", $51.7 \%$ was in the " $21-30$ age range", $71.5 \%$ was "Single", $58.3 \%$ had "Bachelor's degree", 36.7\% had a monthly income of "1000 TL and below", $38.2 \%$ made use of the fitness center " $3-4$ days" a week while $46.1 \%$ used the fitness center " 2 hours" a week.

Table 2. Distribution of scale scores

\begin{tabular}{|c|c|c|c|c|c|c|c|c|}
\hline & Number of items & $\mathbf{n}$ & Mean & Sd & Skewness & Kurtosis & Min. & Max. \\
\hline Oxford Happiness Scale & 7 & 599 & 3.22 & 0.58 & -0.599 & 0.973 & 1 & 5 \\
\hline Leisure Involvement Scale & 15 & 599 & 3.45 & 0.85 & -0.677 & 0.402 & 1 & 5 \\
\hline Attractiveness & 3 & 599 & 3.34 & 0.98 & -0.428 & -0.440 & 1 & 5 \\
\hline Giving Importance & 3 & 599 & 3.56 & 0.99 & -0.628 & -0.116 & 1 & 5 \\
\hline Social Interaction & 3 & 599 & 3.43 & 0.95 & -0.557 & -0.095 & 1 & 5 \\
\hline Identification & 3 & 599 & 3.57 & 0.95 & -0.707 & -0.130 & 1 & 5 \\
\hline Self-expression & 3 & 599 & 3.32 & 0.93 & -0.429 & -0.195 & 1 & 5 \\
\hline
\end{tabular}

Table 2 presents the distribution of scale scores. Of the participants participating in the research, the arithmetic means of total scores received from the Happiness scale is 3.22 and the standard deviation is 0.58 . In view of the scores of the leisure involvement scale, the lowest factoral mean was seen at the "Self-expression" dimension (3.32) while the highest mean was seen at "Identification" dimension (3.57). 
Table 3. Distribution of scale scores according to gender

\begin{tabular}{lllll}
\hline & \multicolumn{2}{l}{ Female $(\mathrm{N}=260)$} & \multicolumn{2}{l}{ Male $(\mathrm{N}=339)$} \\
\cline { 2 - 5 } & Ort. & $\mathrm{Sd}$ & Ort. & $\mathrm{Sd}$ \\
\hline Oxford Happiness Scale & 5.21 & 1.07 & 5.16 & 1.37 \\
Leisure Involvement Scale & 3.32 & 0.82 & 3.55 & 0.85 \\
Attractiveness & 3.15 & 0.97 & 3.48 & 0.85 \\
Giving Importance & 3.43 & 0.96 & 3.66 & 0.99 \\
Social Interaction & 3.28 & 0.95 & 3.55 & 0.92 \\
Identification & 3.46 & 0.96 & 3.65 & 0.93 \\
Self-Expression & 3.27 & 0.91 & 3.40 & 0.94 \\
\hline
\end{tabular}

In Table 3, the OHS scores of the participants do not show a significant difference according to the gender variable $(t=-1.626 ; p>0.05)$. MANOVA results suggest that fundamental effect of gender variable on LIS sub-factors is significant $[\lambda=0.968, F(5.593)=3.979, p<0.05]$. When examined at the level of sub-factors, it was concluded that there were significant differences in "Attractiveness" $[\mathrm{F}(1.597)=2.236, \mathrm{p}<0.05]$, "Giving Importance" $[\mathrm{F}(1.597)=.371, \mathrm{p}<0.05]$, "Social Interaction" $[\mathrm{F}(1.597)=.340, \mathrm{p}<0.05]$ and "Identification" $[\mathrm{F}(1.597)=1.073$, $p<0.05$ ] in terms of gender variable. In all of these sub-dimensions where significant differences were detected, the average mean scores of the males were higher than those of females.

Table 4. Distribution of scale scores according to marital status

\begin{tabular}{lllll}
\hline & \multicolumn{2}{l}{ Married $(\mathrm{N}=171)$} & \multicolumn{2}{l}{ Single $(\mathrm{N}=428)$} \\
\cline { 2 - 5 } & Mean & $\mathrm{Sd}$ & Mean & $\mathrm{Sd}$ \\
\hline Oxford Happiness Scale & 3.27 & 0.62 & 3.20 & 0.56 \\
Leisure Involvement Scale & 3.46 & 0.96 & 3.45 & 0.80 \\
Attractiveness & 3.34 & 0.37 & 3.33 & 0.98 \\
Giving Importance & 3.58 & 0.96 & 3.52 & 0.95 \\
Social Interaction & 3.46 & 0.85 & 3.42 & 0.91 \\
Identification & 3.58 & 0.52 & 3.54 & 0.991 \\
Self-expression & 3.42 & 0.95 & 3.31 & 0.92 \\
\hline
\end{tabular}

In Table 4, the OHS scores of the participants do not show a significant difference according to their marital status $(\mathrm{t}=1.304 ; \mathrm{p}>0.05)$. Manova results reveal that the fundamental effect of the marital status on the LIS sub-factors is not significant $[\lambda=0.990, \mathrm{~F}(5.593)=1.179, \mathrm{p}>0.05]$.

Table 5. Distribution of scale scores according to educational status

\begin{tabular}{lllllll}
\hline & \multicolumn{2}{l}{ High School $(\mathrm{N}=137)$} & \multicolumn{2}{l}{ Assoc. Degree $(\mathrm{N}=113)$} & \multicolumn{2}{l}{ Bachelor's $(\mathrm{N}=349)$} \\
\cline { 2 - 6 } & Mean & $\mathrm{Sd}$ & $\mathrm{Mean}$ & $\mathrm{Sd}$ & $\mathrm{Mean}$ & $\mathrm{Sd}$ \\
\hline Oxford Happiness Scale & 3.32 & 0.58 & 3.25 & 0.61 & 3.18 & 0.56 \\
Leisure Involvement Scale & 3.76 & 0.80 & 3.49 & 0.73 & 3.31 & 0.87 \\
Attractiveness & 3.64 & 0.35 & 3.35 & 0.90 & 3.21 & 0.46 \\
Giving Importance & 3.84 & 0.90 & 3.68 & 0.86 & 3.40 & 0.97 \\
Social Interaction & 3.81 & 0.87 & 3.41 & 0.83 & 3.29 & 0.97 \\
Identification & 3.89 & 0.86 & 3.68 & 0.86 & 3.40 & 0.97 \\
Self-expression & 3.61 & 0.86 & 3.35 & 0.90 & 3.24 & 0.95 \\
\hline
\end{tabular}

According to Table 5, there is no significant difference between the OHS scores and education status of the participants $(\mathrm{F}=2.939 ; \mathrm{p}>0.05)$. MANOVA results indicate that the fundamental effect of educational status on the sub-factors of LIS is significant $[\lambda=0.933, \mathrm{~F}(10.118)=4.147, \mathrm{p}<0.05]$. When we examined the results at sub-factor level, it was concluded that there was a significant difference among the sub-dimensions in terms of educational status as in "Attractiveness" $[\mathrm{F}(2.596)=2.109, \mathrm{p}<0.05]$, "Giving Importance" $[\mathrm{F}(2.596)=5.279, \mathrm{p}<$ 0.05], "Self-expression" $[\mathrm{F}(2.596)=1.422, \mathrm{p}<0.05]$, "Social Interaction" $[\mathrm{F}(2.596)=2.439, \mathrm{p}<0.05]$ and "Identification" $[\mathrm{F}(2.596)=4.912, \mathrm{p}<0.05]$. In all sub-dimensions where there was a significant difference, the average scores of high school graduates were higher than the average scores of other participants. 
Table 6. Correlation results among the age, income, OHS and LIS scores

\begin{tabular}{|c|c|c|c|c|c|c|c|c|}
\hline & Age & Income & Happiness & Attractiveness & $\begin{array}{l}\text { Giving } \\
\text { Importance }\end{array}$ & $\begin{array}{l}\text { Social } \\
\text { Interaction }\end{array}$ & Identification & Self-expression \\
\hline Age & 1 & & & & & & & \\
\hline Income & $0.45^{*}$ & 1 & & & & & & \\
\hline Happiness & 0.86 & 0.32 & 1 & & & & & \\
\hline Attractiveness & 0.57 & -0.49 & $0.34 * *$ & 1 & & & & \\
\hline Giving & 0.28 & -0.69 & $0.33 * *$ & $0.72 * *$ & 1 & & & \\
\hline \multicolumn{9}{|l|}{ Importance } \\
\hline Social & 0.77 & $-0.83 *$ & $0.31 * *$ & $0.71 * *$ & $0.71 * *$ & 1 & & \\
\hline \multicolumn{9}{|l|}{ Interaction } \\
\hline Identification & 0.49 & $0.89 *$ & $0.32 * *$ & $0.71 * *$ & $0.78 * *$ & $0.72 * *$ & 1 & \\
\hline Self-expression & 0.92 & -0.42 & $0.34 *$ & $0.64 * *$ & $0.63 * *$ & $0.71 * *$ & $0.71 * *$ & 1 \\
\hline
\end{tabular}

Note. ${ }^{*}$ Correlation is significant at the 0.05 level (2-tailed).

** Correlation is significant at the 0.01 level (2-tailed).

Table 6 presents the correlation results among the participants' Ages, Income Status, Happiness levels and leisure involvement levels. In line with the analysis results, while the correlation coefficients between the ages of the participants and their scores in OHS were found to be positively significant, and a significant difference was detected between the income status and the "Social Interaction" and "Identification" sub-dimensions among the OHS and LIS sub-factors while there was no significant difference found among the other sub-dimensions. The correlation coefficients between the scores obtained from the OHS and LIS factors were found to be positively significant at a medium and high level. As a result of the regression analysis, it was determined that the leisure involvement levels of the participants were a meaningful predictor of their happiness levels $(\mathrm{R}=0.35 ; \mathrm{R} 2=0.14$; $\mathrm{F}(2.596)=20.692 ; \mathrm{p}<0.01) .14 \%$ of the total variance regarding the happiness levels can be explained by leisure involvement levels.

\section{Discussion and Conclusion}

This study not only determines the happiness and leisure involvement levels of the individuals with fitness center memberships in relation to leisure time activities, it also makes contributions to the recreation literature by investigating the concept of "leisure involvement" which can make significant contributions to people when they are in a pursuit of various solution ways to overcome their problems in daily life and be happy along with its relationship with the happiness levels of the individuals. In this respect, the aim of this study conducted on the individuals who have fitness center memberships and who make use of these fitness centers in Kayseri; is to analyze the relationship between the levels and reasons of the participants to have interest in leisure involvement activities and happiness in view of various variables and to determine if there is a significant difference or not.

In the research, no significant difference was found between the LIS and OHS in view of the gender variable ( $p>$ 0.05). The underlying reason behind this result is that there was no significant difference in view of the gender variable as the participants couldn't reach the clearly desired level of satisfaction and delight between the leisure involvement levels and happiness levels. When examined at the level of sub-factors, it was determined that the gender variable showed significant difference in the "Attractiveness", "Giving Importance", "Social Interaction" and "Identification" sub-dimensions $(\mathrm{p}<0.05)$. Additionally, it was determined that this significant difference was higher on the part of the men in all sub-dimensions. In the study conducted by Aydin (2016) on the individuals using the fitness centers, it was determined that there was no significant difference in terms of gender between the LIS and OHS, however, when the sub-factors were examined in terms of gender variable, the study showed a significant difference in favor of men in "Attractiveness", "Giving Importance" and "Social Interaction" dimensions. In the study that Kocaer (2018) conducted on prospective teachers, it was stated that leisure involvement and utility levels for recreation activities did not reveal a significant difference according to gender. These results are similar to our study.

When examined in terms of the marital status variable, it was determined that there were no significant differences in the LIS and OHS sub-factors of the individuals taking part in the study ( $p>0.05)$. While Aydın (2016), in the study he conducted, reported no significant difference in the LIS sub-dimensions in view of the marital status variable, he also reported a significant difference in OHS scores in view of the marital status variable and that this difference was in favor of the married individuals. Ardahan and Yerlisu Lapa (2011), according to the data obtained from the study they conducted on the individuals on bicycle tours, while the $44.3 \%$ of the individuals were married, the ratio of the couples participating in activities with their spouses was $13.2 \%$. This can be 
explained by the fact that those who are married and who are interested in leisure activities alone or with their friends see leisure activities as areas of development for new social environment and new group of friends.

In accordance with the data obtained from the study, the OHS scores of the participants did not show a significant difference according to their educational status $(\mathrm{p}>0.05)$. When the LIS sub-factor scores were examined, a significant difference was found according to education variable $(\mathrm{p}<0.05)$. It was concluded that this difference in educational status differed in the "Attractiveness", "Giving Importance", "Self-expression", "Social interaction" and "Identification" sub-dimensions $(\mathrm{p}<0.05)$. It was detected that the mean scores of the high school-graduate participants were higher than the scores of the other participants in all sub-dimensions with significant differences. Aydın (2016), in his study, found that there was no significant difference between SISI and OMI according to the education variable, but showed a significant difference in all sub-dimension scores. He stated that this difference was in favor of high school graduates in all sub-dimensions. In another study, Tanır (2009) stated that there is a significant difference between participation in free time activities according to the education variable in the study conducted with students in secondary education institutions. In his study, Aydın (2016) found that there was no significant difference between LIS and OHS according to the education variable and yet, it showed a significant difference in all sub-dimension scores. It was also stated that this difference was in favor of the high school graduates in all sub-dimensions. In another study, Tanır (2009) found a significant difference in leisure time activities according to the education variable as a result of the study he conducted on the students in secondary education institutions.

When the age, income status, happiness levels and leisure involvement of the participants were analyzed according to different variables, it was found that the individuals' scores in OHS were positively significant $(\mathrm{p}<0.05)$, and significant differences were detected between income status and "Social Interaction" and "Identification" sub-dimensions of OHS and LIS sub-factors $(\mathrm{p}<0.05)$, while there was no significant difference in other sub-dimensions $(p>0.05)$. When the scores obtained from OHS and LIS sub-factors were analyzed, they were found to be positively significant at medium and high level $(\mathrm{p}<0.05)$.

According to the data obtained from the research, it was determined that the leisure involvement levels of the participants were a meaningful predictor of the level of happiness. In view of the findings of similar studies related to the relationship between leisure involvement and level of happiness within the body of literature, in the study conducted by Kocaer (2018) on prospective teachers, it was reported that as the level of leisure involvement increased, the utility level of the recreation activities also increased. In the study Yasarturk et al. (2017) conducted on university students, it was reported that as the level of satisfaction perceived by the students taking part in recreational activities increased, the level of life satisfaction increased synchronously. In his study conducted on university students, Dogan (2018) determined that as the leisure involvement motivation increased, the level of happiness also increased. Reich and Zautra (1981) stated that the continuous leisure involvement in leisure activities reduced the level of daily stress and increased happiness psychologically (Karaçar, 2019). As a result, it can be suggested that the increase in leisure involvement levels can induce an increase in the level of happiness of the individuals.

\section{References}

Akova, B., Yesilbursa, D., Sekir, U., Gür, H., \& Serdar, A. (2005). Myocardial Performance and Aortic Elastic Properties in Elite Basketball and Soccer Players: Relationship With Aerobic And Anaerobic Capacity. Journal of Sports Science \& Medicine, 4(2), 185.

Ardahan, F., \& Lapa, T. Y. (2010). Üniversite Öğrencilerinin Serbest Zaman Tatmin Düzeylerinin Cinsiyete Ve Gelire Göre İncelenmesi. Spor Bilimleri Dergisi, 21(4), 129-136.

Ardahan, F., \& Lapa, T. Y. (2011). Açık alan rekreasyonu: bisiklet kullanıcıları ve yürüyüşüülerin doğa sporu yapma nedenleri ve elde ettikleri faydalar. Uluslararasi İnsan Bilimleri Dergisi, 8(1), 1327-1341.

Aydın, İ. (2016). Fitnes Katılımcılarının Rekreasyonel Etkinliklere Yönelik Illgilenim ve Mutluluk Düzeylerinin Belirlenmesi. Gazi Üniversitesi Sağlık Bilimleri Enstitüsü, Yüksek Lisans Tezi, Ankara

Bailey, A., \& Fernando, K. (2012) Routine and Project-Based Leisure, Happiness, and Meaning in Life. Journal of Leisure Reserach, 44(2), 139-154. https://doi.org/10.1080/00222216.2012.11950259

Brajssa, Z. A., Merkas, M., \& Sverko, I. (2011). Quality of life and leisure activities: how do leisure activities contribute to subjective well-being? Social Indicators Research, 102(1), 81-91. https://doi.org/10.1007/s11205-010-9724-2

Broadhurst, R. (2001). Managing Environments for Leisure and Recreation. GBR: Routledge. https://doi.org/10.4324/9780203457306 
Çelik G. (2011). Kamu Kuruluşlarında Çalışan Engelli Bireylerin Serbest Zaman Engellerinin ve Tatmin Düzeylerinin Incelenmesi (Antalya Merkez Örneği). Akdeniz Üniversitesi Sosyal Bilimler Enstitüsü. Yüksek Lisans Tezi, Antalya.

Cenkseven, Ö. F., \& Sarı, M. (2009). Öğretmenler Arasında Öznel İyi Oluşun Öngörüsü Olarak Okul Yaşamının ve Tükenmişliğin Kalitesi. Eğitim Bilimleri: Kuram ve Uygulama, 9(3), 1223-1235.

Çivitçi,A. (2012).Üniversite Öğrencilerinde Genel Yaşam Doyumu ve Psikolojik İhtiyaçlar Arasındaki İlişkiler. Ç.Ü. Sosyal Bilimler Enstitüsü Dergisi, 21(2), 321-336

Çuhadar, A., Demirel, M., Er, Y., \& Serdar, S. (2019). Lise Öğrencilerinde Boş Zaman Yönetimi ve Gelecek Beklentisi İlişkisi. Uluslararası Sosyal Araştırmalar Dergisi, 12(66), 1498-1505. https://doi.org/10.17719/jisr.2019.3689

Çuhadar, A., Er, Y., Demirel, M., \& Demirel, D. H. (2019). Bireyleri Rekreasyonel Amaçli Egzersize Motive Eden Faktörlerin İncelenmesi. SPORMETRE Beden Eğitimi ve Spor Bilimleri Dergisi, 17(3), 153-161.

Demirel, D. H., Demirel, M., \& Serdar, E. (2017). University Students' Opinions of the Meaning of Leisure and Their Perceived Freedom in Leisure. Journal of Human Sciences, 14(1), 796-802. https://doi.org/10.14687/jhs.v14i1.4340

Demirel, M., \& Harmandar, D. (2009). Üniversite Öğrencilerinin Rekreasyonel Etkinliklere Katılımlarında Engel Oluşturabilecek Faktörlerin Belirlenmesi. Uluslararası İnsan Bilimleri Dergisi, 6(1), 838-846.

Doğan, M. N. (2018). Hukuk Fakültesi Öğrencilerinin Rekreasyonel Aktivitelerden Elde Ettikleri Faydaların ve Mutluluk Düzeylerinin İncelenmesi. Gazi Üniversitesi Sağlık Bilimleri Enstitüsü. Yüksek Lisans Tezi, Ankara.

Doğan, T., \& Çötok, N. A. (2011). Oxford Mutluluk Ölçeği Kısa Formunun Türkçe Uyarlaması: Geçerlik ve Güvenirlik Çalışması. Türk Psikolojik Danışma ve Rehberlik Dergisi, 4(36).

Eskiler, E., \& Karakaş, G. (2017). Sakarya Üniversitesi Öğrencilerinin Serbest Zaman İlgilenimleri İle Davranışsal Niyetleri Arasındaki İlişkilerinin İncelenmesi. İstanbul Üniversitesi Spor Bilimleri Dergisi, 7(3), $10-24$.

Göral, Ş. (2013). Internet Ortamında Geçirilen Boş Zamanın Üniversite Öğrencilerinin Mutluluk Ve Yaşam Doyum Değerlerine Etkisi. Gazi Üniversitesi Sağlık Bilimleri Enstitüsü, Yüksek Lisans Tezi, Ankara.

Gürbüz, B., Çimen, Z., \& Aydın, İ. (2018). Serbest Zaman İlgilenim Ölçeği: Türkçe Formu Geçerlik ve Güvenirlik Çalışması. Spormetre Beden Eğitimi Ve Spor Bilimleri Dergisi, 16(4), 256-265. https://doi.org/10.1501/Sporm_0000000374

Havitz, M. E., Kaczynski, A. T., \& Mannell, R. C. (2013). Exploring Relationships Between Physical Activity, Leisure Involvement, Self-Efficacy, And Motivation Via Participant Segmentation. Leisure Sciences: An Interdisciplinary Journal, 35(1), 45-62. https://doi.org/10.1080/01490400.2013.739890

Hills, P., \& Argyle, M. (2002). The Oxford Happiness Questionnaire: a compact scale for the measurement of psychological well-being. Personality and Individual Differences, 33, 1073-1082. https://doi.org/10.1016/S0191-8869(01)00213-6

Karaçar, E. (2019). Spor Fakültesinde Okuyan Öğrencilerin Rekreaktif Faaliyetlere Karşı İlgi ve Mutluluk Düzeyleri: Sinop Üniversitesi Örneği. Spor ve Rekreasyon Araştırmaları Dergisi, 1(1), 58-70.

Karasar, N. (2012). Bilimsel Araştırma Yöntemi (23. Basım) Ankara: Nobel.

Karlı, Ü., Polat, E., Yılmaz, B., \& Koçak, S. (2008). Serbest Zaman Tatmin Ölçeği’nin (SZTÖ-uzun versiyon) geçerlilik ve güvenilirlik çalışması. Spor Bilimleri Dergisi, 19(2), 80-91.

Koç, K., \& Pepe, O. (2018). The Investigation of the Relationship between Happiness Levels of the Faculty of Sports Sciences and the Levels of Life Satisfaction and Optimism. World Journal of Education, 8(6), 74-81. https://doi.org/10.5430/wje.v8n6p74

Koç, K., \& Turan, M. B. (2018). The Impact of Cultural Intelligence on Social Skills among University Students. Journal of Education and Learning, 7(6), 241-249. https://doi.org/10.5539/jel.v7n6p241

Kocaer, G. (2018). Beden Eğitimi ve Spor Öğretmenleri ve Adaylarının Öğretmenlik Mesleğine Yönelik Tutum, Serbest Zaman Illgilenim ve Rekreasyon Faaliyetlerine Yönelik Fayda Düzeyleri Arasindaki İlişkinin İncelenmesi (Bartın İli Örneği). Bartın Üniversitesi Eğitim Bilimleri Enstitüsü. Yüksek Lisans Tezi, Bartın.

Koçak, F. (2017). The Relationship Between Leisure Constraints, Constraint Negotiation Strategies and 
Facilitators with Recreational Sport Activity Participation of College Students. College Student Journal, 51(4), 491-497.

Kyle, G. T., Absher, J., Norman, W., Hammit, W., \& Jodice, L. (2007). Modified involvement scale. Leisure Studies, 26(4), 398-427. https://doi.org/10.1080/02614360600896668

Lin, H. C., Chen, K. Y., \& Kuo, K. P. (2014). Relationship Between Leisure İnvolvement and Subjective Well-Being: Moderating Effect of Spousal Support. South African Journal for Research in Sport, Physical Education and Recreation, 36(1), 131-146.

Marar, Z. (2004). Mutluluk Paradoksu (S. Çağlayan, Çev.). İstanbul: Kitap Yayınevi. (Eserin Aslı 2003’Te Yayımlanmıştır).

Özdemir, Y., \& Koruklu, N., (2011). Üniversite Öğrencilerinde Değerler ve Mutluluk Arasındaki İlişkinin İncelenmesi.. YYÜ, Ĕgitim Fakültesi Dergisi, VIII(I), 190-210.

Reich, J. W., \& Zautra, A. (1981). Life events and personal causation: some relationships with satisfaction and distress. Journal of Personality and Social Psychology, 41, 1002-1012. https://doi.org/10.1037/0022-3514.41.5.1002

Roberts, K. (2006). Leisure in contemporary society (2. bask1) Wallingford, UK: Cabi. https://doi.org/10.1079/9781845930691.0000

Serdar, E., \& Ay, S. M. (2016). Üniversite Öğrencilerinin Serbest Zaman Etkinliklerine Katılım Biçimlerine Göre Tatmin Olma ve Algılanan Özgürlük Düzeylerinin İncelenmesi Özet. Sosyal Bilimler Dergisi, 3(9), 365-374. https://doi.org/10.16990/SOBIDER.3332

Sevin, H., \& Şen, K. (2019). Öğretmenlerin Rekreasyon Aktivitelerine Katılım Düzeyleri İle Yaşam Mutluluğu ve İş Performansları Arasındaki İliş̧ki. Dini Araştırmalar, 22(55), 213-232. https://doi.org/10.15745/da.564201

Soyer, F., Yıldız, N. O., Demirel, D. H., Serdar, E., Demirel, M., Ayhan, C., \& Demirhan, O. (2017). The Investigation of the Relationship Between the Factors That Prevent University Students from Attending to the Recreational Activities and the Life Satisfaction of the Participants. Journal of Human Sciences, 14(2), 20352046. https://doi.org/10.14687/jhs.v14i2.4647

Stebbins, R. A. (2016). Serbest Zaman Fikri (Temel İlkeler, Demirel M., Ekinci, N., E., Üstün, Ü., D., Işık, U., Gümüş̧ül, O. Çev.), Spor Yayınevi ve Kitabevi, Ankara.

Tanır, Z. (2009). İstanbul ili Ortaögretim Kurumlarındaki Öğrencileririn Serbest Zaman Faaliyetlerinin Dağılımı Ve Değerlendirilmesi. Beykent Üniversitesi Sosyal Bilimler Enstitüsü. Yüksek Lisans Tezi, İstanbul.

Tezcan, M. (1994). Boş Zamanları Değerlendirme Sosyolojisi. Ankara: Atilla Kitabevi.

Tolukan E. (2010). Özel Yenetekle İlgili Bölümlerde Okuyan Üniversite Ögrrencilerinin Rekreasyonel Aktivitelere Katılımlarına Engel Olabilecek Unsurların Belirlenmesi. Niğde Üniversitesi Sosyal Bilimler Enstitüsü, Yüksek Lisans Tezi, Niğde.

Turan, M. B., \& Koç, K. (2018). Analysis of the Relationship between Ego Identity Status and Personality Traits and General Self-Efficacy with Structural Equation Modeling. Higher Education Studies, 8(4), 190-199 https://doi.org/10.5539/hes.v8n4p190

Tuzgöl, D. M. (2004). Öznel İyi Oluş Ölçeğinin Geliştirilmesi: Geçerlik ve Güvenirlik Çalışması. Türk Psikolojik Danışma ve Rehberlik Dergisi, 3(23), 103-111.

Yalçın, C., Demirel, M., Demirel, D. H., \& Çolakoğlu, T. (2017). Beden Eğitimi ve Spor Yüksekokulu Öğrencilerinin Boş Zamanın Anlamı İle Akıllı Telefon Bağımlılıklarına İlişkin Görüşlerinin İncelenmesi. İstanbul Üniversitesi Spor Bilimleri Dergisi, 7(1), 1-11.

Yaşartürk, F., Akyüz, H., \& Karataş, İ. (2017). Rekreatif etkinliklere katılan üniversite öğrencilerinin serbest zamanda sıkılma algısı ile yaşam doyum düzeyleri arasındaki ilişkinin incelenmesi. Uluslararası Kültürel ve Sosyal Araştırmalar Dergisi (UKSAD), 3(Special Issue 2), 239-252.

Yetim, G., \& Argan, M. (2018). Boş Zaman İlgilenim Faktörleri İle Fitness Merkezine Yönelik Tatmin ve Sadakat Arasındaki İliş̧i. Anadolu Üniversitesi Sosyal Bilimler Dergisi, 18(1), 49-62. 


\section{Copyrights}

Copyright for this article is retained by the author, with first publication rights granted to the journal.

This is an open-access article distributed under the terms and conditions of the Creative Commons Attribution license (http://creativecommons.org/licenses/by/4.0/). 